\title{
Peningkatan Kemampuan Koneksi dan Self Efficacy Matematis melalui Model Learning Cycle 7E
}

\author{
Fera Anindya Bunga Asmara ${ }^{1}$, Susilawati ${ }^{2 *}$, Nenden Mutiara Sari ${ }^{3}$ \\ 1,2,3Pendidikan Matematika, Universitas Pasundan, Bandung, Indonesia; \\ ${ }^{1}$ feraasmara0910@gmail.com; ${ }^{2^{*}}$ susilawatichy25@gmail.com; ${ }^{3}$ nenden.mutiara@unpas.ac.id
}

Info Artikel: Dikirim: 17 Juni 2020; Direvisi: 17 September 2020; Diterima: 2 Maret 2021

Cara sitasi: Asmara, F. A. B., Susilawati, S., \& Sari, N. M. (2021). Peningkatan Kemampuan Koneksi dan Self Efficacy Matematis melalui Model Learning Cycle 7E. JNPM (Jurnal Nasional Pendidikan Matematika) 5(1), 160-172.

\begin{abstract}
Abstrak. Penelitian ini bertujuan untuk mengetahui peningkatan kemampuan koneksi matematis dan self efficacy siswa yang memperoleh pembelajaran model Learning Cycle $7 E$. Metode yang digunakan dalam penelitian ini adalah metode kuasi eksperimen dengan desain penelitian kelompok kontrol pretes-postes. Populasi dalam penelitian ini adalah seluruh siswa kelas XI di salah satu SMA negeri di Garut. Untuk sampel penelitiannya terdiri dari 2 kelas. Instrumen yang digunakan dalam penelitian ini berupa soal uraian tes kemampuan koneksi matematis dan skala self efficacy. Data yang terkumpul kemudian diolah menggunakan software SPSS 20.0 for windows. Hasil penelitian menunjukkan bahwa peningkatan kemampuan koneksi matematis siswa yang memperoleh pembelajaran model Learning Cycle 7E lebih baik daripada siswa yang memperoleh model pembelajran biasa; peningkatan self efficacy siswa yang memperoleh pembelajaran model Learning Cycle $7 E$ lebih baik daripada siswa yang memperoleh model pembelajaran biasa; tidak terdapat korelasi antara kemampuan koneksi matematis dan self efficacy siswa yang memperoleh pembelajaran model Learning Cycle 7E.
\end{abstract}

Kata Kunci: Learning Cycle 7E, Koneksi Matematis, Self efficacy

\begin{abstract}
This study aims to determine the increase in mathematical connection skills and self efficacy of students who have learned the $7 E$ Learning Cycle model. The method used in this research is a quasiexperimental method with a pretest-posttest control group research design. The population in this study were all students of class XI. The research sample consisted of 2 classes. The instrument used in this study was a description of the mathematical connection ability test and a self efficacy scale. The collected data was then processed using SPSS 20.0 for windows software. The results showed that the improvement of the mathematical connection ability of students who obtained the $7 E$ Learning Cycle model was better than students who obtained the ordinary learning model; the increase in self efficacy of students who received the $7 E$ Learning Cycle model was better than students who received the ordinary learning model; there is no correlation between the mathematical connection ability and self efficacy of students who have learned the $7 E$ Learning Cycle model.
\end{abstract}

Keywords:Learning Cycle 7E, Mathematical Connection, Self efficacy

\section{Pendahuluan}

Pembelajaran matematika di sekolah tidak dapat dipisahkan dari definisi matematika. Matematika adalah ilmu universal yang berguna bagi kehidupan 
manusia, mendasari perkembangan teknologi modern, berperan dalam berbagai ilmu, dan memajukan daya pikir manusia (Permendikbud, 2014). Saragih, Elvis \& Amin (2017) mengemukakan bahwa visi pendidikan matematika di Indonesia dikhususkan untuk memahami konsep dan ide matematika yang kemudian diterapkan dalam pemecahan rutin dan non-rutin melalui pengembangan penalaran, komunikasi dan koneksi matematika. Pembelajaran matematika dapat membantu siswa untuk berpikir secara sistematis, melalui urutan-urutan yang teratur dan tertentu. Ruseffendi (2006) berpendapat bahwa dalam matematika setiap konsep itu berkaitan dengan konsep lain, begitu pula antara yang lainnya misalnya antara dalil dan dalil, antara teori dan teori, antara topik dengan topik, antara cabang matematika.

Penelitian yang dilakukan oleh Saminanto \& Kartono (2015) menunjukkan bahwa rata-rata kemampuan koneksi matematis siswa sekolah menengah masih rendah, yakni hanya berada pada nilai 34\%. Selain itu, penelitian yang dilakukan oleh Badjeber \& Fatimah (2015) juga menunjukkan bahwa rata-rata kemampuan koneksi matematis siswa sekolah menengah masih rendah, yakni hanya berada pada nilai 34\% siswa yang dapat mengkoneksikan antara ide matematis.. Sejalan dengan hal itu Manalu, Septiahani, Permaganti, Melisari, \& Yeti (2020) dalam penelitiannya mengatakan bahwa kemampuan koneksi matematis siswa sedang, ini terlihat dari persentasi kesalahan yang dilakukan siswa pada indikator mengenali dan menerapkan matematika dalam kontekkontek di luar matematika. Ulya, Irawati, \& Maulana(2016) mengemukakan juga bahwa berdasarkan hasil observasi yang dilakukan terlihat bahwa kemampuan siswa dalam mengkoneksi ide-ide antar matematika masih kurang. Hal ini terjadi dikarenakan masih adanya anggapan bahwa matematika merupakan pelajaran yang sulit, menakutkan dan hanya sebatas hapalan yang cukup dihapal saja tanpa memandang adanya kaitan dari materi tersebut dengan materi lainnya. Hal ini menggambarkan bahwa kemungkinan yang menjadi masalah adalah kemampuan koneksi matematis siswa yang masih rendah.

Rohendi \& Dulpaja (2013) mengemukakan bahwa kemampuan koneksi matematika diperlukan oleh siswa, terutama di pemecahan masalah yang membutuhkan hubungan antara konsep matematika ke konsep lain dalam matematika dan disiplin ilmu lainnya atau dalam kehidupan nyata. Sejalan dengan itu Sari, Mardiyana, \& Pramudya (2020) dalam penelitiannya mengatakan bahwa melalui koneksi matematika siswa dapat menggunakan ide-ide matematika yang berkaitan dengan masalah nyata, siswa dapat membangun kembali pemahaman mereka tentang pengetahuan sebelumnya dan siswa lebih terbiasa dengan hal-hal baru jika mereka didasarkan pada 
konsep yang mereka tahu. Dengan kemampuan koneksi matematis siswa diharapkan untuk dapat mengenali dan menggunakan hubungan antara ideide matematika, memahami bagaimana ide-ide matematika saling berhubungan dan mendasari satu sama lain untuk menghasilkan yang bersatu utuh, dan mengenali serta menerapkan matematika di luar konteks matematika.

Selain kemampuan kognitif yang penting yang harus dimiliki siswa, kemampuan afektif juga penting untuk dimiliki siswa. Karena kemampuan afektif merupakan kemampuan penunjang agar pendidikan di Indonesia dapat lebih baik. Kemampuan afektif tersebut adalah self efficacy (efikasi diri). Menurut Todor (2014), self efficacy didefinisikan sebagai keyakinan orang tentang kemampuan mereka untuk mendapatkan tingkat kinerja yang diharapkan.Sedangkan Arifin (2019) mengemukakan bahwa self efficacy adalahpercayaakan kemampuan untuk memperoleh performa yang diinginkan, dimanadalam self efficacy matematikamerupakan suatu keadaan atau masalah yang spesifik dari kepercayaan diri siswa tentang kemampuannya untuk dapat berhasil menyelesaikan berbagai tugas atau menyelesaikan masalah. Sejalan dengan hal itu, Maulani, Amalia,\& Zanthy(2020) self efficacy merupakan aspek psikologis yang memberikan pengaruh signifikan terhadap keberhasilan siswa dalam menyelesaikan tugas dan pertanyaan-pertanyaan penyelesaian masalah dengan baik. Self efficacy mempengaruhi pilihan tindakan yang akan dilakukan dan besarnya usaha ketika menemui kesulitan dan hambatan. Individu yang memiliki self efficacy tinggi memilih untuk melakukan usaha lebih besar dan tidak mudah putus asa.

Berdasarkan hasil penelitian Febriana, Rahmi, \& Putri (2020) mengemukakan bahwa $70 \%$ siswa memperoleh nilai dibawah rata-rata kelas. Hal ini disebabkan oleh kurangnya self efficacy diri yang dimiliki siswa. Novferma (2016) juga menjelaskan bahwa rendahnya self efficacysiswa pada matematika ditunjukkan oleh banyak dari mereka yang tidak ingin mencoba menyelesaikan soal. Mereka cenderung menyerah ketika menghadapi tugas-


terbukti ketika guru meminta siswa mengerjakan soal latihan di papan tulis, terlihat siswa tidak mau untuk mengerjakan dan tidak percaya diri apakah pekerjaannya benar. Ferdyansyah, Rohaeti, \& Suherman (2020) juga mengatakan bahwa jika siswa yang memiliki self efficacy rendah maka siswa akan semakin sulit siswa untuk menuntaskan pembelajaran di sekolah. 
Untuk meningkatkan kemampuan koneksi matematis dan self efficacy siswa proses pembelajaran yang berorientasi pada peserta didik (student oriented) menjadi salah satu pilihan yang tepat. Untuk mencapai upaya tersebut, guru dapat melakukan inovasi dalam pembelajaran baik pada model pembelajaran, strategi, pendekatan, metode maupun media pembelajaran. Inovasi yang dapat dilakukan adalah dengan penggunaan model pembelajaran yang diharapkan dapat meningkatkan kemampuan koneksi dan self efficacy siswa SMA adalah model Learning Cycle 7E.

Menurut Alfin, Hidayati, Hadi, \& Rosidi (2020) Learning Cycle 7E adalah model pembelajaran yang berpusat pada kegiatan siswa dan didasarkan pada konstruktivisme. Sedangkan Rahmy, Usodo, \& Slamet(2020) mengemukakan bahwa Learning Cycle $7 E$ adalah model pembelajaran yang berpusat pada siswa yang terdiri dari tujuh fase yaitu elicit, engage, explore, explain, elaborate, evaluate, and extend. Sejalan dengan hal itu menurut Nur, Prihatiningtyas, \& Rosmaiyadi (2020) model Learning Cycle 7E merupakan model pembelajaran yang berpusat pada siswa (student centered) yang mengadopsi dari prinsip konstruktivisme. Model ini memiliki 7 tahapan pembelajaran, yaitu: (1) Elicitit (memperoleh); (2) Engange (melibatkan); (3) Explore (menjelajahi); (4) Explain (menjelaskan); (5) Elaborate (menguraikan); (6) Evaluate (menilai); (7) Extend (memperluas).

Bahri \& Adiansha (2020) menjelaskan bahwa tujuan Learning Cycle 7E untuk menekankan pentingnya peningkatan Cycle $7 E$ sebelumnya tentang pemahaman dan memperluas atau mentransfer suatu konsep. Sedangkan menurut Balta\& Sarac (2016), tujuan utama Learning Cycle 7E adalah untuk menekankan semakin pentingnya pemahaman sebelumnya tentang bagaimana cara mentransfer konsep ke konteks baru.

Tujuan dari penelitian ini adalah untuk menelaah peningkatan kemampuan koneksi matematis siswa yang memperoleh pembelajaran model Learning Cycle 7E lebih baik daripada siswa yang memperoleh model pembelajaran biasa, menelaah self efficacy siswa yang memperoleh pembelajaran model Learning Cycle $7 E$ lebih baik daripada siswa yang memperoleh model pembelajaran biasa dan mengetahui terdapat korelasi positif antara kemampuan koneksi matematis dan self efficacy siswa yang memperoleh model Learning Cycle 7E.

\section{Metode}

Metode yang digunakan dalam penelitian ini adalah metode penelitian kuasi eksperimen, sebab penelitian ini dilakukan untuk mengetahui hubungan 
antara perlakuan yang diberikan dengan aspek tertentu yang akan diukur. Perlakuan yang diberikan dalam penelitian ini yaitu berupa model Learning Cycle $7 E$, sedangkan aspek yang akan diukur yaitu kemampuan koneksi matematis dan self efficacy siswa. Populasi dalam penelitian ini adalah seluruh siswa kelas XI pada tahun ajaran 2017/2018. Pengambilan sampel dalam penelitian ini dilakukan dengan menggunakan teknik purposive sampling, yaitu dengan memilih 2 kelas yang sudah terbentuk dan kelas yang dipilih berdasarkan pertimbangan guru matematika yang bersangkutan dengan pertimbangan bahwa penyebaran siswa tiap kelas merata ditinjau dari segi kemampuan akademiknya. Kelas eksperimen yang memperoleh model Learning Cycle $7 E$ dan kelas kontrol memperoleh model pembelajaran konvensional, diperoleh kelas XI MIPA 2 sebanyak 32 orang sebagai kelas eksperimen dan kelas XI MIPA 1 sebanyak 32 orang sebagai kelas kontrol.

Prosedur penelitian ini dilakukan dalam tiga tahapan (Gambar 1), sebagai berikut.

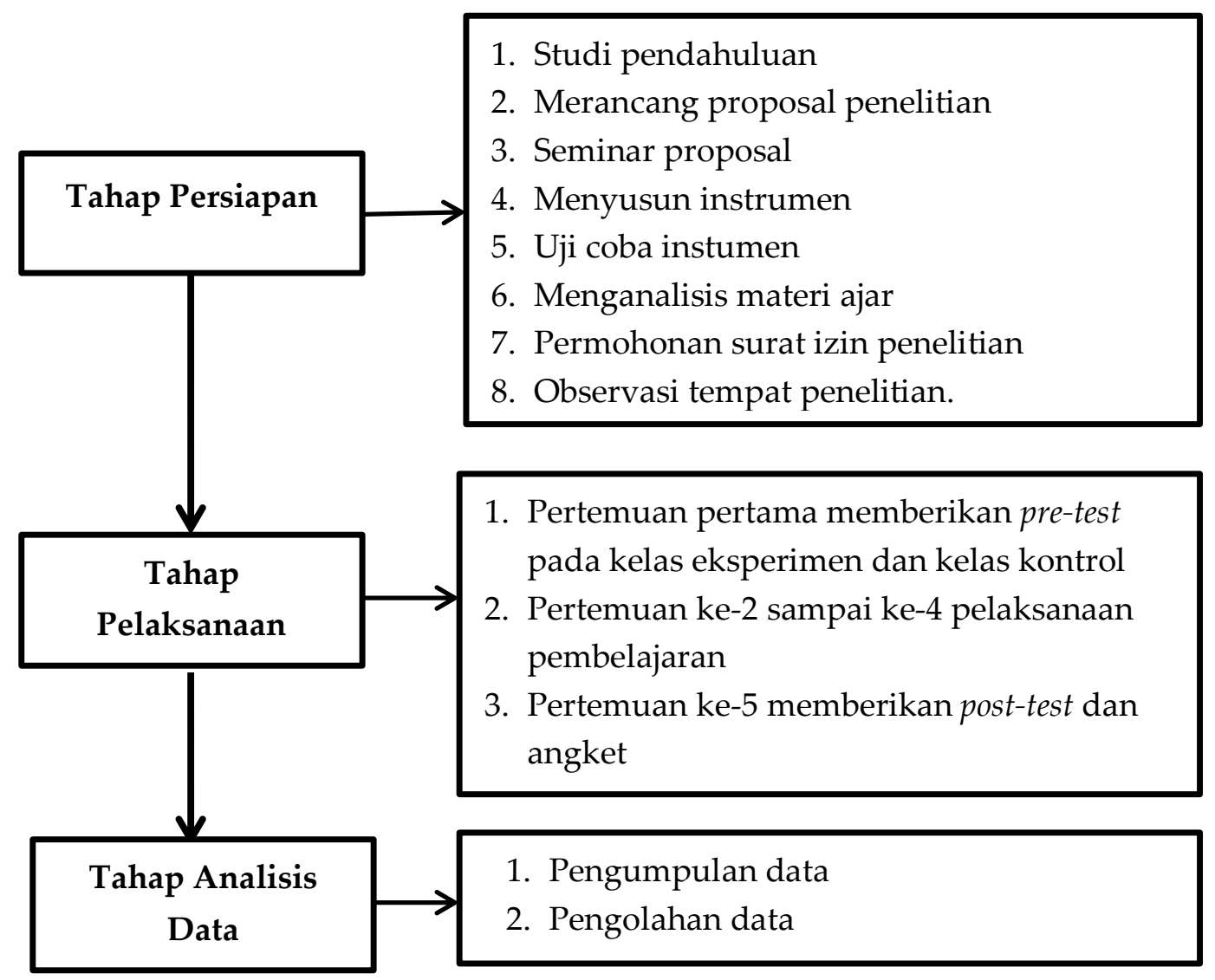

Gambar 1. Tahapan Penelitian

Instrumen dalam penelitian ini terdiri atas tes dan non tes. Instrumen tes kemampuan koneksi matematis yang dilakukan adalah pre-test dan post-test, 
sebanyak 6 butir soal materi integral dengan indikator kemampuan koneksi matematis. Sedangkan instrumen non tes terdiri atas angket self efficacy sebanyak 30 pernyataan. Sebelum dilaksanakan pengujian data instrumen diuji cobakan terlebih dahulu kepada kelas yang lebih tinggi untuk melihat validitas, reliabilitas, indeks kesukaran dan daya pembeda instrumen tes.

Selanjutnya untuk mengetahui kualitas peningkatan kemampuan koneksi matematis siswa kelas eksperimen dan kelas kontrol setelah dilakukan pembelajaran dengan menggunakan model Learning Cycle 7E dan model pembelajaran biasa dapat dilihat dari data gain. Data skor gain kedua kelas dianalisis mengggunakan statistik deskriptif, uji normalitas, uji homogenitas dua varians, dan uji kesamaan dua rerata. Sedangkan untuk analisis data skala self efficacy kelas eksperimen dan kelas kontrol, data skala self efficacy menggunakan bantuan Method of Successive Interval (MSI) pada software Microsoft Excel 2010. Kemudian, menggunakan statistik deskriptif, uji normalitas, uji homogenitas, dan uji kesamaan dua rerata.

\section{Hasil dan Pembahasan}

Berdasarkan hasil skor pre-test dan post-test pada tes kemampuan koneksi matematis dengan menggunakan statistik deskriptif diperoleh skor minimum $\left(\mathrm{X}_{\min }\right)$, skor maksimum $\left(\mathrm{X}_{\max }\right)$, skor rata-rata, simpangan baku dan varians dari data skor gain. Data disajikan pada Tabel 1 berikut:

Tabel 1. Statistik Deskriptif Tes Kemampuan Koneksi Matematis

\begin{tabular}{cccccccccccc}
\hline & & \multicolumn{4}{c}{ Pre-test } & \multicolumn{5}{c}{ Post-test } \\
Kelas & $\mathrm{N}$ & $\mathrm{X}$ & $\mathrm{X}_{\min }$ & $\overline{\mathrm{x}}$ & $\mathrm{S}$ & $\mathrm{S}$ & $\mathrm{X}_{\mathrm{ma}}$ & $\mathrm{X}_{\mathrm{mi}}$ & $\overline{\mathrm{x}}$ & $\mathrm{S}$ & $\mathrm{s}$ \\
& & $\max$ & & & & & $\mathrm{x}$ & $\mathrm{n}$ & & & \\
\hline Eksperimen & 32 & 55 & 15 & 35,8 & 11,7 & 137,21 & 85 & 55 & 73,3 & 7,746 & 60,00 \\
Kontrol & 32 & 50 & 12 & 34,3 & 10,6 & 113,06 & 75 & 50 & 63,1 & 6,522 & 42,54 \\
\hline
\end{tabular}

Tabel 1 menunjukkan bahwa rata-rata indeks gain skor hasil pretes yang diperoleh siswa kelas eksperimen sebesar 35,8 artinya kelas eksperimen mempunyai peningkatan kemampuan koneksi matematis yang tergolong sedang dan rata-rata indeks gain siswa kelas kontrol sebesar 34,3 artinya kelas kontrol mempunyai peningkatan kemampuan koneksi matematis yang tergolong sedang. Berdasarkan indeks gain, hasil tersebut menunjukkan bahwa rata-rata peningkatan kemampuan koneksi matematis siswa kelas eksperimen dan kelas kontrol tergolong sedang. Sedangkan hasil dari skor post-test terlihat bahwa rata-rata yang diperoleh kelas eksperimen sebesar 73,3 lebih besar dibandingkan kelas kontrol yang memperoleh rata-rata sebesar 63,1 . 
Selanjutnya, untuk mengetahui peningkatan kemampuan koneksi matematis siswa yang telah dicapai menggunakan data gain ternormalisasi menurut Rohim \& Susanto (2012) sebagai berikut.

Gain ternormalisasi $(\mathrm{N}$-gain $)=\frac{\text { skorpostest-skorpretes }}{\text { Skormaks-skorpretes }}$

Tabel 2. Deskriptif Statistik Data Gain Kelas Eksperimen dan Kelas Kontrol

\begin{tabular}{ccccccc}
\hline \multirow{2}{*}{ Kelas } & \multirow{6}{c}{ Kemampuan Koneksi Matematis } \\
& & $X_{\max }$ & $X_{\min }$ & $\bar{x}$ & $\mathrm{~S}$ & $\mathrm{~s}$ \\
\hline Eksperimen & 32 & 0,82 & 0,17 & 0,5603 & 0,17009 & 0,029 \\
Kontrol & 32 & 0,71 & 0,11 & 0,4263 & 0,12422 & 0,015 \\
\hline
\end{tabular}

Berdasarkan Tabel 2 di atas terlihat bahwa kualifikasi rerata gain kelas eksperimen sebesar 0,5603 dan kelas kontrol sebesar 0,4263.

Hipotesis uji normalitas data skor gain ternormalisasi kelas eksperimen dan kelas kontrol adalah sebagai berikut:

$\mathrm{H}_{0}$ : Sebaran data berdistribusi normal

$\mathrm{H}_{\mathrm{a}}$ : Sebaran data berdistribusi tidak normal

Uji normalitas data skor gain ternormalisasi diolah menggunakan software IBM SPSS 20 yang hasilnya disajikan pada Tabel 3 sebagai berikut:

Tabel 3. Uji Normalitas Data Gain

\begin{tabular}{cccc}
\hline \multirow{2}{*}{ Kelas } & \multicolumn{3}{c}{ Kemampuan Koneksi Matematis } \\
& Statistic & Df & Sig. \\
\hline Eksperimen & 0,948 & 32 & 0,129 \\
Kontrol & 0,981 & 32 & 0,830 \\
\hline
\end{tabular}

Tabel 3 menunjukkan bahwa signifikansi uji Shapiro Wilk pada skor gain kemampuan koneksi matematis kelas eksperimen yaitu 0,129 >0,05 dan kelas kontrol 0,830>0,05. Artinya data gain kemampuan koneksi matematis kelas eksperimen dan kelas kontrol berdistribusi normal karena untuk signifikansi yang lebih besar dari 0,05 berarti $\mathrm{H}_{0}$ diterima.

Berdasarkan uji normalitas distribusi data gain ternormalisasi menunjukan bahwa kedua kelas berdistribusi normal sehingga analisis dilanjutkan dengan menguji homogenitas dua varians data postes antara kelas eksperimen dan kelas kontrol dengan menggunakan uji Leven's test for equality melalui software IBM SPSS 20 dengan taraf signifikansi 0,05. Dan jika signifikansi > 0,05, maka dapat disimpulkan bahwa data berasal dari populasi yang mempunyai 
varians yang sama. Hasil uji kesamaan dua rerata dapat dilihat pada Tabel 4 berikut ini:

Tabel 4. Uji Homogenitas Dua Varians Data Gain

\begin{tabular}{cccc}
\hline \multicolumn{4}{c}{ Kemampuan Koneksi Matematis } \\
\hline Levene Statistic & df1 & df2 & Sig. \\
\hline 3,735 & 1 & 62 & 0,058 \\
\hline
\end{tabular}

Tabel 4 menunjukkan bahwa signifikansi uji Levene pada skor data gain kemampuan koneksi matematis kelas eksperimen dan kelas kontrol yaitu 0,058 > 0,05. Signifikansi tersebut lebih besar dari 0,05 sehingga $\mathrm{H}_{0}$ diterima. Dari hasil uji homogenitas tersebut dapat disimpulkan bahwa data gain kemampuan koneksi matematis kelas eksperimen dan kelas kontrol mempunyai varians yang homogen.

Selanjutnya dilakukan uji kesamaan dua rerata untuk gain ternormalisasi kemampuan koneksi matematis siswa dengan uji-t melalui software IBM SPSS 20.0 menggunakan Independent Sampel T-Test. Hipotesis statistik yang diuji adalah.

$$
\begin{aligned}
& H_{0}: \mu_{1} \leq \mu_{2} \\
& H_{a}: \mu_{1}>\mu_{2}
\end{aligned}
$$

dengan:

$\mathrm{H}_{0}$ : Kemampuan koneksi matematis siswa yang memperoleh model Learning Cycle $7 E$ tidak lebih baik daripada siswa yang memperoleh model pembelajaran biasa.

$\mathrm{H}_{\mathrm{a}}$ Kemampuan koneksi matematis siswa yang memperoleh model Learning Cycle $7 E$ lebih baik daripada siswa yang memperoleh model pembelajaran biasa.

Hasil dari uji kesamaan dua rerata gain ternormalisasi kemampuan koneksi matematis dapat dilihat pada Tabel 5 berikut ini:

Tabel 5. Uji Kesamaan Dua Rerata Data Gain

\begin{tabular}{cccc}
\hline & \multicolumn{3}{c}{ t-test for Equality of Means } \\
& $\mathrm{T}$ & Df & Sig. (2-tailed) \\
\hline $\begin{array}{c}\text { Equal variances } \\
\text { assumed }\end{array}$ & 3,601 & 62 & 0,001 \\
\hline
\end{tabular}

Tabel 5 menunjukkan bahwa nilai signifikansi dengan taraf signifikansi 0,05 adalah 0,001. Karena nilai signifikansi kurang dari 0,05 maka $\mathrm{H}_{0}$ ditolak dan $\mathrm{H}_{\mathrm{a}}$ diterima. Artinya dapat disimpulkan bahwa peningkatan kemampuan 
koneksi matematis siswa yang memperoleh model Learning Cycle 7E lebih baik daripada siswa yang memperoleh model pembelajaran biasa.

Data tentang self efficacy diperoleh melalui angket yang diberikan pada pertemuaan akhir pembelajaran pada kedua kelas yaitu kelas eksperimen dan kelas kontrol. Data skala self efficacy siswa kelas eksperimen dan kelas kontrol terlebih dahulu diubah menjadi data interval menggunakan bantuan Method of Successive Interval (MSI) pada software Microsoft Excel 2010. Untuk melihat perbedaan self efficacy kelas eksperimen dan kelas kontrol dilakukan uji kesamaan dua rerata melalui Independent Sampel T-Test dengan menggunakan software IBM SPSS 20.0. Hipotesis statistik uji Independent Sampel T-Test sebagai berikut.

Dengan:

$$
\begin{aligned}
& H_{0}: \mu_{1} \leq \mu_{2} \\
& H_{a}: \mu_{1}>\mu_{2}
\end{aligned}
$$

$\mathrm{H}_{0}$ : Self efficacy siswa yang memperoleh model Learning Cycle 7E tidak lebih baik daripada siswa yang memperoleh model pembelajaran biasa.

$\mathrm{H}_{\mathrm{a}}$ Self efficacy siswa yang memperoleh model Learning Cycle 7E lebih baik daripada siswa yang memperoleh model pembelajaran biasa.

Berdasarkan hasil pengujian persyaratan analisis data yaitu uji normalitas dan uji homogenitas diketahui bahwa kedua kelas berdistribusi normal dan memiliki varians yang homogen sehingga uji kesamaan dua rerata dilakukan dengan menggunakan uji-t.

Hasil uji kesamaan dua rerata dapat dilihatpada Tabel 6 berikut ini:

Tabel 6. Uji Kesamaan Dua Rerata Data Self-efficacy

\begin{tabular}{cccccc}
\hline \multicolumn{7}{c}{$\begin{array}{c}\text { Levene's Test for Equality } \\
\text { for Variances }\end{array}$} & & & \\
& $\mathrm{F}$ & Sig. & T & Df & Sig (2-tailed) \\
\hline $\begin{array}{c}\text { Angket Equal } \\
\text { variances } \\
\text { assumed }\end{array}$ & 1,075 & 0,304 & 5,879 & 62 & .000 \\
\hline
\end{tabular}

Tabel 6 menunjukkan bahwa nilai signifikansi dengan uji-t skor self efficacy kelas eksperimen dan kelas kontrol yaitu 0,000 <0,05. Karena signifikansi

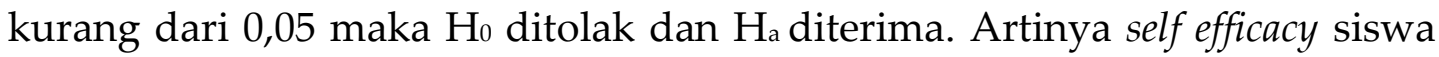
yang memperoleh model Learning Cycle 7E lebih baik daripada siswa yang memperoleh model pembelajaran biasa. 
Berdasarkan hasil penelitian, siswa yang memperoleh model Learning Cycle $7 E$ memiliki self efficacy yang lebih baik dibandingkan dengan siswa yang memperoleh model pembelajaran biasa. Selain dibuktikan dari hasil perhitungan angket, hal ini terlihat pada saat proses pembelajaran.

Pada kelas yang memperoleh model Learning Cycle $7 E$, terdapat tahapan dimana siswa belajar secara berkelompok yang dapat membantu meningkatkan keyakinan siswa tentang materi yang dipelajarinya. Walaupun materi yang dipelajarinya terasa sulit namun siswa merasa terbantu jika belajar bersama teman kelompoknya karena terkadang siswa lebih merasa santai jika bertanya pada temannya. Sehingga siswa yang memperoleh model Learning Cycle 7E dapat memiliki keyakinan dan kemampuan untuk mengatur, melaksanakan, dan mendapatkan keberhasilan sesuai yang diharapkan. Sedangkan pada kelas PB siswa belajar secara individu, hanya beberapa siswa yang bertanya pada guru tentang keraguannya.

Berdasarkan hasil penelitian, tidak terdapat korelasi antara kemampuan koneksi matematis dan self efficacy siswa yang memperoleh model Learning Cycle 7E. Sejalan dengan hasil penelitian tersebut Shafa (2016) mengatakan bahwa tidak terdapat hubungan antara kemampuan koneksi matematis dengan self efficacy. Kondisi tersebut menunjukkan bahwa pengaruh antara kemampuan koneksi matematis terhadap self efficacydan pengaruh kondisi tersebut menunjukan bahwa pengaruh antara kemampuan koneksi matematis terhadap self efficacy dan pengaruh self efficacy terhadap kemampuan koneksi matematis masih tergolong lemah.

Apriani, Sujana, \& Kurnia (2016) menyatakan bahwa kelebihan dari model pembelajaran ini adalah peserta didik dilibatkansecara aktif dalam proses pembelajaran serta mampu mengembangkan potensi individu yangberhasil dan berguna, kreatif, bertanggung jawab, mengaktualisasikan dan mengoptimalkandirinya terhadap perubahan yang terjadi, sehingga pembelajaran menjadi lebih bermakna. Sejalan dengan itu, penelitian ini memberikan gambaran bahwa model Learning Cycle 7E dapat memberikan sumbangan yang lebih baik terhadap kemampuan koneksi matematis siswa dibandingkan dengan model pembelajaran biasa, sehingga dapat dijadikan sebagai wahana untukmengembangkan kemampuan koneksi matematis siswa dan mampu mengaplikasikannya dalam kehidupan sehari-hari. Sejalan dengan penelitian ini Francis\&Mabel(2015) mengatakan bahwa pembelajaran yang menggunakan Learning Cycle $7 E$ lebih efektif dibandingkan dengan pembelajaran konvensional. Nabilah, Suhendra, \& Yulianti (2018) juga 
mengemukakan bahwa model Learning Cycle 7E dapat meningkatkan kemampuan koneksi matematika. Nabilah, Suhendra, \& Yulianti (2018) juga mengatakan kemampuan koneksi matematika siswa yang memperoleh Learning Cycle 7E lebih baik daripada siswa yang memperoleh pembelajaran

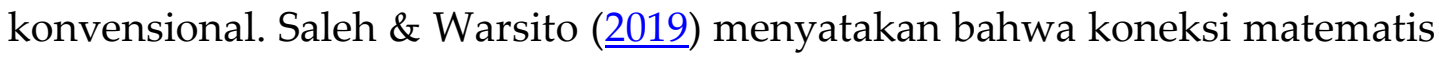
yang menggunakan pembelajaran Learning Cycle 7Elebih baik dibandingkan dengan koneksi matematis yang menggunakan pembelajaran konvensional. Hasil penelitian lain juga menunjukan bahwa peningkatan kemampuan koneksi matematis siswa yang memperoleh pembelajaran menggunakan model pembelajaran Learning Cycle 7E lebih baik daripada siswa yang memperoleh pembelajaran konvensional (Purnamasari, 2017). Shafa \& Ghaida (2016) juga memaparkan hasil penelitiannya yaitu model pembelajaran Learning Cycle 7E dapat meningkatkan kemampuan koneksi matematis siswa SMA dan peningkatan kemampuan koneksi matematis siswa dengan model pembelajaran Learning Cycle 7E lebih baik dari pada siswa yang mempeloreh pembelajaran konvensional.

Model Learning Cycle 7E juga dapat memberikan sumbangan yang lebih baik terhadap self efficacy siswa, sehingga siswa memiliki kemampuan dan keyakinan terhadap diri sendiri ataupun lingkungannya. Sejalan dengan hal itu Nabilah, Suhendra, \& Yulianti (2018) mengemukakan bahwa sebagian besar siswa memberikan sikap positif terhadap Learning Cycle 7E. Hasanah, Rosyida, \& Dewi (2019) juga mengemukakan bahwa Learning Cycle 7E dapat meningkatkan self efficacy siswa selama pembelajaran matematika. Model pembelajaran yang menyenangkan, aktif dan mengembangkan keyakinan diri siswa akan membuat self efficacy siswa tinggi. Hasil penelitian lainnya dikemukakan bahwa ada peningkatan self efficacy siswa yang memperoleh pembelajaran menggunakan model pembelajaran Learning Cycle 7E lebih baik daripada siswa yang memperoleh pembelajaran konvensional (Purnamasari, 2017). Shafa \& Ghaida (2016) juga mengemukakan bahwa sebagian besar siswa memberikan sikap positif terhadap model pembelajaran Learning Cycle $7 E$.

\section{Simpulan}

Peningkatan kemampuan koneksi matematis siswa yang memperoleh pembelajaran dengan menggunakan model Learning Cycle 7E lebih baik daripada siswa yang memperoleh pembelajaran biasa. Hasil self efficacy siswa yang memperoleh pembelajaran dengan menggunakan model Learning Cycle $7 E$ lebih baik daripada siswa yang memperoleh pembelajaran biasa. Dan tidak terdapat korelasi antara kemampuan koneksi matematis dan self efficacy siswa yang memperoleh pembelajaran model Learning Cycle 7E. 


\section{Daftar Pustaka}

Alfin, M. B., Hidayati, Y., Hadi, W. P., \& Rosidi, I. (2020). Analisis Kemampuan Berpikir Kritis Siswa Terhadap Pembelajaran Hypothetico-Deductive Reasoning Dalam Learning Cycle 7E. Jurnal Penelitian Pendidikan IPA, 4(2), 75-81.

Apriani, D., Sujana, A., \& Kurnia, D. (2016). Penerapan model pembelajaran learning cycle pada materi perubahan sifat benda untuk meningkatka hasil belajar siswa. Jurnal Pena Ilmiah, 1(1):781-790.

Arifin, N. (2019). Upaya Meningkatkan Self-Efficacy Siswa Dalam Pembelajaran Matematika Melalui Problem Based Learning. Pendas Mahakam: Jurnal Pendidikan Dasar, 3(3), 255266.

Balta, N., \& Sarac, H. (2016). The Effect of $7 E$ Learning Cycle In Science Teaching : A meta Analisys Study. European Journal of Education Research 5(2), 61-72.

Badjeber, R., \& Fatimah, S. (2015). Peningkatan Kemampuan Koneksi Matematis Siswa SMP melalui Pembelajaran Inkuiri Model Alberta. Jurnal Pengajaran MIPA 2(1). 18-26.

Bahri, S., \& Adiansha, A. A. (2020). Pengaruh Model Learning Cycle 7E dan Kecerdasan Interpersonal Terhadap Pemahaman Konsep IPA. Jurnal Pendidikan Anak, 6(1), 44-51.

Febriana, R., Rahmi, R., \& Putri, G. E. (2020). Pengaruh Self-Efficacy terhadap Pemahaman Konsep Matematika dengan Menerapkan Model Discovery Learning pada Siswa Kelas XI MIA 1 SMA N 5. Edumatica: Jurnal Pendidikan Matematika, 10(1), 27-34.

Ferdyansyah, A., Rohaeti, E., \& Suherman, M,M. (2020). Gambaran Self Efficacy Terhadap Pembelajaran. FOKUS 3(1), 1-10.

Francis, A. A., \& Mabel, I. I. (2015). Effects Of 7e Learning Cycle Model And Case-Based Learning Strategy On Secondary School Students' Learning Outcomes In Chemistry. JISTE 19 (1), 110.

Hasanah, U., Rosyida, I., \& Dewi, R, N. (2019). Mathematics Communication Skill Seen from Self-Efficacy of Junior High School Students on 7E Learning Cycle with Ethnomathematics Nuances. UJMER 10(2), 190-196.

Manalu, S, C, A., Septiahani, A., Permaganti, B., Melisari, M., \& Yeti. (2020). Analisis Kemampuan Koneksi Matematis Siswa SMK Pada Materi Fungsi Kelas XI. Jurnal Pendidikan Matematika 4(1), 254-260.

Maulani, F. I., Amalia, R., \& Zanthy, L. S. (2020). Kontribusi Self Efficacy Terhadap Prestasi Belajar Matematika Pada Siswa Sma. MAJU: Jurnal Ilmiah Pendidikan Matematika, 7(1), 110.

Nabilah, Suhendra, S., \& Yulianti K. (2019). The Efforts Of Improving Mathematical Connection Ability Of Senior High School Student With 7e Learning Cycle Model. Journal of Physics: Conference Series 1157(4), 1-8.

Nopiyani, D., Turmidi, \& Prabawanto, S. (2016). Penerapan Pembelajaran Matematika Realistik Berbantuan GeoGebra untuk Meningkatkan Kemampuan Komunikasi Matematis Siswa SMP. Mosharafa: Jurnal Pendidikan Matematika, 5(2), 45-52.

Novferma, N. (2016). Analisis Kesulitan Dan Self-Efficacy Siswa SMP Dalam Pemecahan Masalah Matematika Berbentuk Soal Cerita. Jurnal Riset Pendidikan Matematika, 3(1): 7687.

Nur, M. S., Prihatiningtyas, N. C., \& Rosmaiyadi, R. (2020). Kemampuan Representasi Matematis Siswa SMP pada Model Learning Cycle 7E dan Problem Based Learning pada Materi Statistika. Variabel, 3(1), 26-35.

Permendikbud. (2014). Peraturan Menteri Pendidikan dan Kebudayaan Republik Indonesia Nomor 59 Tahun 2014 Tentang Kurikulum 2013 Sekolah Menengah Atas/Madrasah Aliyah. Jakarta: 
Departemen Pendidikan dan Kebudayaan.

Purnamasari, S. R. (2017). Penerapan Model Learning Cycle 7e (Elicit, Engange, Explore, Explain, Elaborate, Evaluate, And Extend) Untuk Meningkatkan Kemampuan Koneksi Matematis Dan Self-Efficacy Siswa Sma (Doctoral dissertation, FKIP UNPAS).

Rahmy, S. N., Usodo, B., \& Slamet, I. (2020). Students' mathematical communication ability using 7E learning cycle based on students thinking style. JPhCS, 1469(1), 012154.

Rohendi, D., \& Dulpaja. (2013). Connected Mathematics Project (CMP) Model Based on Presentation Media on the Mathematical Connection Ability of Junior High School Student. Journal of Educational and Practice, 4(4), 17-22.

Rohim, F., \& Susanto, H. (2012). Penerapan model discovery terbimbing pada pembelajaran fisika untuk meningkatkan kemampuan berpikir kreatif. UPEJ Unnes Physics Education Journal, 1(1), 1-10.

Ruseffendi, E. T. (2006). Pengantar kepada membantu guru mengembangkan kompetensinya dalam pengajaran matematika untuk meningkatkan CBSA. Bandung: tarsito.

Saleh, H., \& Warsito, W. (2019). Peningkatan Kemampuan Koneksi Matematis Mahasiswa Melalui Pembelajaran Model Siklus 7e Berbantuan Hypnoteaching. Prima: Jurnal Pendidikan Matematika, 3(2), 158-174.

Saminanto, \& Kartono. (2015). Analysis of Mathematical Connection Ability in Linear Equation With One variable Based on Connectivity Theory. International Journal of Education and Research, 3(4), 259-270.

Saragih, S., Napitupulu, E. E \& Amin Fauzi. (2017). Developing Learning Model Based on Local Culture and Instrument for Mathematical Higher Order Thinking Ability. International Education Studies, 10(6), 114-124.

Sari, D. N. O., Mardiyana, M., \& Pramudya, I. (2020). Analysis of the ability of mathematical connections of middle school students in the field of algebra. JPhCS, 1469(1), 012159.

Shafa, N., \& Ghaida, R. (2016). Upaya Meningkatkan Kemampuan Koneksi Matematis Siswa Sma Dengan Model Pembelajaran Learning Cycle $7 e$ (Doctoral dissertation, Universitas Pendidikan Indonesia).

Todor, I. (2014). The Old Stereotype about Boys/Girls and Mathematics: Gender Differences in Implicit Theory of Intelligence. Procedia (Elseiver) - Social and Behavioral Sciences, $159,319-323$.

Ulya, I. F., Irawati, R., \& Maulana, M. (2016). Peningkatan Kemampuan Koneksi Matematis Dan Motivasi Belajar Siswa Menggunakan Pendekatan Kontekstual. Jurnal Pena Ilmiah, 1(1), 121-130. 